\title{
THE LEGAL STATUS OF MINOR TESTATOR'S PARENTS DEPRIVED OF PARENTAL AUTHORITY IN INTESTATE SUCCESSION. SOME REMARKS ON THE SOLUTIONS IN POLISH, RUSSIAN, AND ITALIAN LAW
}

\author{
Hanna Witczak
}

ABSTRACT

The legal situation of minor testator's parents in intestate succession poses a significant legal and social problem. In Polish law, parents who have been deprived of parental authority continue to enjoy their civil-law status; in other words, they maintain the right to inherit from their child under statute. Meanwhile, the reasons for which the court applied the strictest possible "sanction" in the form of deprivation of authority of parents who, in exercising their rights under parental authority, seriously violated the child's interest or grossly neglected parental obligations, which is noticeable even to an ordinary bystander, seem to be sufficient "proof" that family ties, which are decisive for the statutory title to inherit, do not exist. If these ties are severed or seriously disrupted, the consequences should be seen in all areas of life. Simply put, persons who deliberately break apart the family should not enjoy the advantages that the law provides for testator's closest relatives. In such a case, to consider the effect of deprivation of parental authority by "releasing" its holders from any obligation towards the child may not be considered a sufficient civil sanction, especially given that in the vast majority of cases, the reason for such deprivation is gross neglect of parental duties by one or both parents. The consequences of this type of negligence should also, if not primarily, consist in the deprivation of pecuniary benefits that the parents of a minor could

Dr. habil. Hanna Witczak, Associate Professor, Faculty of Law, Canon Law and Administration, The John Paul II Catholic University of Lublin; correspondence address: Al. Racławickie 14, 20-950 Lublin, Poland; e-mail: hwitczak@poczta.fm; https://orcid.org/ 0000-0002-5949-3052. 
enjoy after his or her death. The current legal solutions governing this area undoubtedly need to be revised. Such imperfect normative solutions adopted in Polish law prove the need to propose de lege ferenda recommendations. In this context, it is worthwhile to have a look at the normative solutions adopted in foreign legal systems and whether they can be grafted on Polish law. The reference to the Russian and Italian legal systems seems particularly recommendable due to the fact that their normative solutions directly allude to the institution of deprivation of parental authority in the context of admissibility of the title to inherit.

Keywords: deprivation of parental authority, unworthiness to inherit, intestate title to inherit, minor testator

\section{INTESTATE TITLE OF PARENTS TO INHERIT FROM A MINOR AND THE QUESTION OF PARENTAL AUTHORITY}

Next to the capacity to inherit, the intestate title to inherit is a positive prerequisite for the acquisition of an estate. It is based on a specific relationship under family law ${ }^{1}$ existing between a testator and a potential heir upon the opening of the succession and demonstrable through civil-status certification documents ${ }^{2}$. Family ties in the legal sense, and conclusive for intestate succession, exist when a testator and their heirs share a particular line and degree of relationship ${ }^{3}$ upon the opening of the succession. Thus, proof of a linear relationship in the first degree between a testator and an heir upon the opening of the succession is a necessary condition to be met for legal succession to take place ${ }^{4}$. Parents are the second line of

1 See, for example, Józef S. Piątowski, Hanna Witczak, and Agnieszka Kawałko, "Dziedziczenie ustawowe," in System Prawa Prywatnego. Tom 10. Prawo spadkowe, ed. Bogudar Kordasiewicz (Warszawa: C.H. Beck, 2015), 229-230, Nb 18.

2 See Article 4 of the Act of 28 November 2014 - Law on Civil Status (consolidated text, Journal of Laws of 2021, item 709).

3 Also in relation to marriage (Article $932 \$ 1 \mathrm{CC}$ and Article $932 \$ 2 \mathrm{CC}$ ) and relationship by affinity (Article $934^{1} \mathrm{CC}$ ).

4 See in particular Hanna Witczak, Wytaczenie od dziedziczenia na mocy orzeczenia sądu (Warszawa: LexisNexis, 2013), 45-48. 
intestate succession and inherit the entire estate in equal parts (Article 932 $\$ 3$ of the Civil Code [“CC"]) 5 .

As a rule, until the opening of the succession, a minor testator is subject to parental authority under the first-degree linear kinship (Article 92 of the Polish Family and Guardianship Code, ["FGC"] $)^{6}$, still the existence or non-existence of this relationship does not affect the testator's parents intestate title to inherit. The parents of a minor testator also enjoy the legal title to succession irrespective of whether until the child's death they have exercised the duties inherent in parental authority and, if yes, whether they have done so properly or improperly. Even in the most extreme cases, i.e. deprivation of parental authority due to gross neglect by the parent(s) of their parental duties ${ }^{7}$ (Article $111 \$ 1$ FGC), the mother or father still inherit from their child by virtue of the law ${ }^{8}$. Parents who have been deprived of parental authority continue to enjoy their civil-law status; in other words, they maintain the right to inherit from their child'. If we rightly assume that "a family relationship between parent and child based on love

5 In the second line, along with the testator's parents, there is the testator's spouse, yet this goes beyond the scope of this paper (the testator is a minor).

6 "Parental authority, as follows from the overall provisions of the Family and Guardianship Code, in particular Articles $95 \$ 1,96$ and $98 \$ 1$, constitutes a set of duties and rights in relation to a child that ensure that the child is properly cared for and that their interests are safeguarded (underline H.W.)" - Decision of the Supreme Court of 5 May 2000, II CKN 761/00, LEX no. 51982.

Obviously, as deprivation of parental authority is not of a general nature, when parents have more children, it can only be imposed in relation to one child. Everything depends on where the grounds justifying the deprivation of parental authority occur (Decision of the Supreme Court of 12 September 2000, file ref. III CKN 1143/00, LEX no. 532145).

8 Provided there are no negative grounds for succession exist on their side. For more, see Hanna Witczak, "Skutki wyłączenia od dziedziczenia," Rejent, no. 3 (2009): 73-96.

9 See, for exmaple, Krzysztof Pietrzykowski, "Komentarz do art. 111," in Kodeks rodzinny i opiekuńczy. Komentarz, ed. Krzysztof Pietrzykowski (Warszawa: C.H. Beck, 2020), Legalis, Nb 14; Jerzy Strzebińczyk, "Pozbawienie władzy rodzicielskiej," in Prace z prawa cywilnego dla uczczenia pamięci Profesora Jana Kosika, Acta Universitatis Wratislaviensis. Prawo CCCVIII (Wrocław: Wydawnictwo Uniwersytetu Wrocławskiego, 2009), 491; idem, "Władza rodzicielska," in System Prawa Prywatnego. Tom 12. Prawo rodzinne i opiekuńcze, ed. Tadeusz Smyczyński (Warszawa: C.H. Beck, 2011), 358, Nb. 266 and Iwona Długoszewska, Przestanki oraz skutki ograniczenia i pozbawienia wtadzy rodzicielskiej (Warszawa: 
is, as a rule, a sufficient guarantee for the exercise of parental authority" ${ }^{10}$ and that the same family relationship determines the mutual title to inherit, it is difficult not to see a fundamental paradox in this situation. Indeed, the assumption underlying the concept of the institution of parental authority, under which parents guarantee due and even best possible care for their child, sometimes appears so erroneous that the only solution is to deprive them of parental authority ${ }^{11}$. In view of the fact that the vast majority of cases of withdrawal of parental authority are attributed to reprehensible and culpable behaviour of parents towards their minor child, the moral justification of inheriting from a testator is not at all compelling, and consequently, the fitness of the relevant legislative solutions should remain open to question. The mere fact that decisions on withdrawal of parental authority are issued relatively rarely, given the number of children under authority and other judicial decisions interfering with the exercise of parental authority, does not downplay the importance of the problem, which is both of a legal and social nature ${ }^{12}$.

\section{INTERNATIONAL, UNLAWFUL CONDUCT BY PARENTS TOWARDS A MINOR TESTATOR AS GROUNDS FOR EXCLUSION FROM THE SUCCESSION V. GROUNDS FOR DEPRIVATION OF PARENTAL AUTHORITY}

There seems to be no doubt that certain intentional behaviour by persons holding a title to inherit that can also be considered unlawful, and therefore violating not only the law but also the principles of social

LexisNexis, 2012), 264. Cf. Jacek Wierciński, "Uwagi o teoretycznych założeniach dziedziczenia ustawowego," Studia Prawa Prywatnego, no. 2 (2009): 84.

10 Decision of the Supreme Court of 20 April 2000, file ref. II CKN 452/00, Lex, no. 52546 , thesis 2 .

11 Jerzy Strzebińczyk, "Pozbawienie władzy rodzicielskiej," in Prace z prawa cywilnego dla uczczenia pamięci Profesora Jana Kosika, Acta Universitatis Wratislaviensis. Prawo CCCVIII (Wrocław: Wydawnictwo Uniwersytetu Wrocławskiego, 2009), 477.

12 See Elżbieta Holewińska-Łapińska, "Orzecznictwo w sprawach o pozbawienie władzy rodzicielskiej," in Prawo w dziataniu. Tom 14. Sprawy cywilne, ed. Elżbieta Holewińska-Łapińska (Warszawa: LEX a Wolters Kluwer Business, 2013), 27. 
coexistence, may give grounds to disinheritance, i.e. deprivation of the right to a reserved share and exclusion from the succession ${ }^{13}$. In the context of the conditions for acquisition of inheritance, unethical or even unlawful behaviour by an heir can only be assessed under civil-law events that result in exclusion from the succession ${ }^{14}$. Certainly, such an assessment is consistent only in relation to heirs who enjoy capacity to inherit and who hold a valid title to inheritance ${ }^{15}$.

In Polish law, intentional and reprehensible behaviour of potential heirs may lead to negative legal consequences when two institutions become applicable: unworthiness to inherit (Articles 928-930 CC) and disinheritance (Articles 1008-1010 CC). As regards debarment from succession (expressis verbis, an unworthy heir is excluded from inheriting as if they had not lived to see the opening of the succession, Article 928(2) CC), it takes place when a constitutive court decision approving the defendant as unworthy to inherit becomes final. The consequences of disinheritance, meaning deprivation of the right to a reserved share of the estate, are to be decided by the testator themselves, as this kind of deprivation may only be expressed in a will (Article 1008 CC) and only for the reasons set out in that provision. Among the grounds for disinheritance, Article 1008 $\mathrm{CC}$ points to: persistent behaviour in contravention of the principles of

13 Cf. Maksymilian Pazdan, "Komentarz do art. 1008," in Kodeks cywilny. Tom II. Komentarz. Art. 450-1088. Przepisy wprowadzajace, ed. Krzysztof Pietrzykowski (Warszawa: C.H. Beck, 2021), Legalis, Nb 1; Elżbieta Skowrońska-Bocian and Jacek Wierciński, in Kodeks cywilny. Komentarz. Spadki. IV, ed. Jacek Gudowski (Warszawa: Wolters Kluwer Polska, 2017), 293, thesis 1-2; Józef Kremis, Komentarz do art. 1008, in Kodeks cywilny. Komentarz, eds. Edward Gniewek and Piotr Machnikowski (Warszawa: C.H. Beck, 2016), 1831-1832, Nb 1 and 10; Elżbieta Skowrońska-Bocian, Testament w prawie polskim (Warszawa: LexisNexis, 2004), 1521; Joanna Kuźmicka-Sulikowska, Komentarz do art. 1008, in Kodeks cywilny. Komentarz, Edward Gniewek, Piotr Machnikowski (Warszawa: C.H. Beck, 2019), Legalis, Nb 1-3 and Hanna Witczak, "O skutkach wydziedziczenia w kontekście przesłanek nabycia spadku,” in Państwo. Konstytucja. Prawo. Księga Pamiątkowa poświęcona Sędziemu Trybunatu Konstytucyjnego Profesorowi Henrykowi Ciochowi, Studia i Materiaty Trybunatu Konstytucyjnego, tom LX (Warszawa: Trybunał Konstytucyjny, 2018), 513-521.

14 Hanna Witczak, "Skutki wyłączenia od dziedziczenia," Rejent, no. 3 (2009): $73-75$.

15 For more, see Hanna Witczak, Wytączenie od dziedziczenia na mocy orzeczenia sądu (Warszawa: LexisNexis, 2013), 57. 
community life contrary to the will of the testator; an intentional offence against life, health or freedom, or a glaring insult to their dignity committed with respect to the testator or one of the persons closest to them; persistent neglecting of family duties with respect to the testator. Due to specific subjective requirements of possessing the capacity to draw up or revoke a will, which is conditioned by full capacity for acts in law (Article 944 $\$ 1 \mathrm{CC}$ ), in view of the discussed topic, the issue of disinheritance, which concerns the parents of a minor testator, must remain outside the sphere of author's interest ${ }^{16}$. Under Polish law, full legal capacity for acts in law is acquired at the moment of becoming an adult, i.e. upon reaching 18 years of age or 16 years of age in the case of women who have entered into a marriage with the consent of the guardianship court (Article 11 CC in conjunction with Article 10 CC).

These individuals cannot be incapacitated by the court (Articles 12 and 15 CC), so cannot be those for whom no temporary advisor has been appointed in the course of proceedings for legal incapacitation (Articles 548 and 549 of the Code of Civil Procedure).

As noted elsewhere, reprehensible behaviour of a potential heir may be a reason for denial of the succession if it meets the conditions for considering them unworthy to inherit. Grounds for unworthiness to inherit are included in Article $928 \$ 1 \mathrm{CC}$ and form a closed list. Of the three of them indicated by the legislator, in the case of a minor testator, only the one specified in Article $928 \$ 1$ (1) CC applies, i.e. intentional perpetration by an heir of a grave offence against the testator ${ }^{17}$. The other two (Article 928(1)(2) and (3) CC) concern the heir's influence on the testator's

16 Grounds for disinheritance would not be difficult to prove when conditions justifying deprivation of parental authority occur, particularly in the event of persistent failure to fulfil family duties with respect to the testator by persons entitled to a reserved share (Article 1008(3) CC).

17 Obviously, unworthiness cannot be adjudged if there are circumstances excluding the unlawfulness of a prohibited act, such as acting in self-defence or in a state of necessity. Unworthiness cannot be adjudged against an insane offender either. For more, see Hanna Witczak, Wytączenie od dziedziczenia na mocy orzeczenia sądu (Warszawa: LexisNexis, 2013), 139-146 and 161-170. 
freedom of will in the manner specified in the relevant provision ${ }^{18}$. As mentioned above, in Polish law, only natural persons with full capacity for acts in law may draw up or revoke a will, which excludes minor testators.

In view of the general considerations above, it is doubtful whether this kind of protection afforded to persons entitled to inherit from a minor testator is sufficient and whether such a system of succession conveys a sense of justice. On the face of it, it seems that the answer to this question should be negative. There are no relevant regulations in the law of succession that would sanction or would make it possible to sanction failure to fulfil family obligations ${ }^{19}$ defined in the law, especial with regard to parent-child relations (Article $95 \$ 1$ FGC), i.e. while the child remains under parental authority. And yet, especially in the case of minor individuals, this type of behaviour should be particularly condemned, not only in moral terms but also, and perhaps above all, legally, and should produce pecuniary consequences as well as depriving the offenders of protection of their financial interests both while the injured party is alive and after their death. Certainly, the abovementioned regulations concerning the option of declaring a parent-heir unworthy to inherit after committing an intentional and grave offence against the testator (Article 928(1)(1) CC) can be used as a counterargument; it is worth noting that for a civil court to declare an heir unworthy, the perpetrator does not have to be convicted by a criminal court or even tried ${ }^{20}$. Although the application of the provision of Article $928 \$ 1$ (1) CC raises certain doubts due to the use by the legislator of the vague term "grave offence," it seems that the character of the injured party somewhat mitigates interpretation difficulties, which is discussed below. While the very concept of offence used in the provision of Article $928 \$ 1$ (1) CC is understood uniformly across the doctrine and jurisprudence owing to reference to concepts in penal law ${ }^{21}$, this is not the case with the term "grave crime." On the one hand, penal law does

18 It is pointless to discuss in detail the cases of violation of the freedom to draw up a will as listed by the legislator, as they do not contribute to the topic of this paper.

19 Especially persistent and culpable conduct.

20 Kazimierz Przybyłowski, "Notka do uchwały SN z dnia 10 września 1958 r. (3 CO 16/58)," OSPiKA, no. 5 (1959): 244.

21 Advocates of the presented view, taking into account an isolated position that equates the offence under Article $928 \$ 1(1)$ CC and a prohibited act, are listed by 
not generally use this term ${ }^{22}$; on the other, the idea of gravity of the offence in the context of unworthiness to inherit should be interpreted along with its ratio legis. No automatic approach is possible, i.e. to recognise that the gravity of an offence is determined solely by the gravity of penalties provided for a particular prohibited act. The objectives of penal and civil law and the sanctions provided for therein are in fact quite divergent. The literature and case-law are right to emphasise that in order to assess whether an offence committed by an heir is grave within the meaning of Article 928(1)(1) CC, it is necessary to consider not only the type of the offence assessed from the point of view of the limits of statutory penalties (crime or misdemeanour) but also the circumstances of the offence, including, in particular, the perpetrator's motives and how they acted. Thus, a civil court makes an independent assessment as to whether, in a specific case, an offence committed by an heir meets the criteria of "gravity." This assessment, as underlined elsewhere, is linked not only to the statutory penalty for this offence, but the court also takes into account the type of threatened interest and the perpetrator's motivation (intent to humiliate or demean the testator in a particularly severe manner), the manner of committing the offence (cruelty, particularly high degree of ill will), the extent of the wrong and, in the author's view, the person wronged ${ }^{23}$. Certainly, it can be assumed that offences with a severe statutory penalty, i.e. those which penal law regards as crimes in abstracto, constitute grave offences, but this is only a preliminary assessment in the context of the provision of Article $928 \$ 1(1)$ CC. The circumstances of a particular case may cause that an act qualified as a crime within the meaning of the provisions of penal law will not be regarded as a serious offence for the purposes of

Hanna Witczak, Wytaczenie od dziedziczenia na mocy orzeczenia sadu (Warszawa: LexisNexis, 2013), 139-140.

22 Cf. Hanna Witczak, Wytaczenie od dziedziczenia na mocy orzeczenia sadu (Warszawa: LexisNexis, 2013), 175-177 and the penal-law literature referenced therein.

${ }_{23}$ See, in particular, Elżbieta Skowrońska, "Przegląd orzecznictwa zzakresu prawa spadkowego (za lata 1989-1990)," Przeglad Sądowy, no. 9 (1992): 43; Maksymilian Pazdan, "Komentarz do art. 928," in Kodeks cywilny. Tom II. Komentarz. Art. 450-1088. Przepisy wprowadzające, ed. Krzysztof Pietrzykowski (Warszawa: C.H. Beck, 2021), Legalis, $\mathrm{Nb} 14$ and Hanna Witczak, Wytaczenie od dziedziczenia na mocy orzeczenia sadu (Warszawa: LexisNexis, 2013), 178-206. 
the aforesaid provision and cannot therefore constitute grounds of adjudging unworthiness to inherit. Also, a reverse situation can take place, namely that under certain circumstances, a misdemeanour may also become a serious offence ${ }^{24}$.

It does not seem going too far to say that conviction for any offence against a minor meets the criteria of committing a grave offence against a testator, especially if the injured party is the convicted person's minor child. Indeed, the view proposed above that the assessment of an offence in terms of gravity should also provide for who is being wronged should be endorsed. Hence, it offences against minors should deserve a special place among serious offences. Harming the life or health of children, both physical and mental, is extremely abhorrent. There should therefore be no doubt as to the seriousness of offences against mental and physical health of minors (e.g. the offence of abuse, not only with particular cruelty Article 207 of the Penal Code; the offence of causing serious damage to health - Article $156 \$ 1$ of the Penal Code), or against their life (e.g. murder or the attempted murder of a minor - Article 148 of the Penal Code), or sexual offences against sexually immature persons (e.g. rape of a minor or forcing him or her to submit to another sexual activity - Article 197 of the Penal Code), which are considered to be among the most serious violations of the broadly understood best interest of the child ${ }^{25}$. Sexual exploitation of children involves the kind of harm that is "not only highly traumatic but also produces serious consequences in emotional, sexual, and social life when becoming an adult" ${ }^{26}$. Among the consequences of sexual abuse, there are, in particular, chronic depression, anxiety disorders, post-traumatic stress disorder, low self-esteem, a tendency to self-harm,

24 See Judgement of the Administrative Court in Gdańsk of 14 June 2000, file ref. I ACa 262/00, LEX no. 51706 with the glosses of Paweł Kłak, OSP, no. 9 (2005): 81-90 and Michał Niedośpiał, OSA, no. 6 (2006): 76-88. See also Jacek Wierciński, "O przestępstwie jako przyczynie niegodności dziedziczenia," Kwartalnik Prawa Prywatnego, no. 2 (2010); for more, see Hanna Witczak, Wytączenie od dziedziczenia na mocy orzeczenia sqdu (Warszawa: LexisNexis, 2013), 213-215.

25 Sławomir Hypś, "Komentarz do art. 200," in Kodeks karny. Komentarz, eds. Alicja Grześkowiak and Krzysztof Wiak (Warszawa: C.H. Beck, 2021), Legalis, Nb. 1.

26 Joanna Mierzwińska-Lorencka, Karnoprawna ochrona dziecka przed wykorzystaniem seksualnym (Warszawa: LEX a Wolters Kluwer Business, 2012), 25. 
a feeling of guilt, sleep and concentration disorders, distorted sexual development, including a tendency to abuse minors after reaching sexual maturity. The literature also highlights the prevalence of post-traumatic psychiatric symptoms, including pathological suspicion, mood lability, and autism ${ }^{27}$. These type of offences affect not one but many interests of the wronged. Extremely severe and prolonged psychological traumas occurs in minor victims of parental incest ${ }^{28}$. The extreme reprehensibility of this phenomenon is not at all lessened by the fact that the above-mentioned types of offences relatively rarely lead to adjudication of unworthiness to inherit, which results from the obvious rule that a child inherits from their parents and not vice versa.

Notably, in the current legal order, a penal court is obliged to notify the competent family court of the need to deprive or limit parental or custodial rights in the event of committing an offence against a minor or in cooperation with a minor (Article 51 of the Penal Code ["PC"]) ${ }^{29}$. However, the PC currently in force does not provide for deprivation of parental (or custodial) authority among its penalties (penal measures) ${ }^{30}$.

27 Sławomir Hypś, “Komentarz do art. 200," in Kodeks karny. Komentarz, eds. Alicja Grześkowiak and Krzysztof Wiak (Warszawa: C.H. Beck, 2021), Legalis, Nb. 2 with the literature referenced therein, and Joanna Mierzwińska-Lorencka, Karnoprawna ochrona dziecka przed wykorzystaniem seksualnym (Warszawa: LEX a Wolters Kluwer Business, 2012), 28.

28 Joanna Mierzwińska-Lorencka, Karnoprawna ochrona dziecka przed wykorzystaniem seksualnym (Warszawa: LEX a Wolters Kluwer Business, 2012), 28 with the literature referenced in Note 11 and p. 47.

29 Violetta Konarska-Wrzosek, in System Prawa Karnego. Tom 6. Kary i środki karne. Poddanie sprawcy próbie, ed. Mirosława Melezini (Warszawa: C.H. Beck, 2010), 875, Nb. 919.

30 It should be recalled that both the Penal Code of 1932 (Article 49) and the Penal Code of 1969 (Article 38(2)) provided for an additional penalty of deprivation of parental or custodial rights. Under Article 49 of the 1932 PC, if convicted of an offence committed against a minor under 17 years of age or in collaboration with such a minor, the court was authorised to adjudge the loss of parental or custodial rights. Compared to the 1932 PC, the option of imposing the penalty of deprivation of parental or custodial rights was extended in the 1969 CP to include offences committed in circumstances where the act had a demoralising effect on a minor, as well as to offences resulting in damage to any minor's property (before, the list of offences had been limited only to acts against a person). See, in particular, Violetta Konarska-Wrzosek, in System Prawa Karnego. Tom 6. Kary i środki 
The exclusion of the possibility for a penal court to decide on withdrawing parental or custodial authority, which is completely wrong, is widely criticised by the doctrine of the protection of minors and other persons in need of third-party care under penal law. Leaving aside the assessment of the purpose of reinstating the penalty of deprivation of parental or custodial authority in the PC, the doctrine of penal law emphasises the substantial damage that such offences cause to the mental and physical capability of the minor, not infrequently leading to pathological states (illness, demoralisation). Indeed, almost any offence may be committed to the detriment of a minor, yet this should not lead to hasty and far-reaching conclusions as to the rationale of imposing, in each of such cases, an additional penalty of deprivation of parental or custodial authority. The literature on the subject has aptly pointed out that these are acts which would disqualify the perpetrator as a person enjoying parental rights. In particular, it would be appropriate to point to those offences where acting against a minor is a prohibited act at law, i.e. physical or mental abuse of a child (Article 207 PC), paedophilia (Article 200 PC), child abandonment (Article 210 PC), encouragement of a minor to drink alcohol (Article 208 PC) or persistent failure to fulfil marital or parental obligations (Article 209 PC) ${ }^{31}$.

However, even if the proposed interpretation of the provision of Article $928 \$ 1$ (1) CC is accepted, the sole institution of unworthiness to inherit does not seem to constitute sufficient protection against admitting the parents of a minor testator to inherit upon the opening of the succession after they have been deprived of their parental authority. First, although the right to act in proceedings for debarment from succession is defined very broadly (the first sentence of Article 929 CC), the time limit for filing a request for declaring an heir unworthy of inheritance (the second sentence of Article 929 CC) is a period of prescription under substantive law, and upon its expiry such a right also expires. Second, reprehensible behaviour of the testator's parents, e.g. gross neglect of family

karne. Poddanie sprawcy próbie, ed. Mirosława Melezini (Warszawa: C.H. Beck, 2010), 866, Nb. 906 and 871, Nb 913. Also, the age limit was increased for victims, up to which perpetrators were deprived of their parental or custodial rights. This was based on the understanding that such protection should continue throughout the period of minority.

31 Mieczysław Goettel, "Pozbawienie praw rodzicielskich w polskim kodeksie karnym," Nowe Prawo, no. 7-8 (1978): 1079. 
duties, even if of a persistent nature, does not have to meet the statutory criteria of a specific type of offence; besides, in view of the procedure of disinheritance adopted in the CC (the requirement to draw up a will), such behaviour will not give grounds for deprivation of the right to a reserved shared of the estate, either. Although deprivation of the right to a reserved share entails the loss of the capacity to inherit from the testator under statute ${ }^{32}$, it should be borne in mind that this applies only to a testator who has the capacity to draw up or revoke a will. Oddly enough, parents who fail to fulfil their parental duties, and have even been deprived of parental authority, are in a more favourable position than other immediate relatives who have persistently failed to fulfil their family responsibilities towards the testator. If they are not declared unworthy to inherit, they will be in a position to claim the entire inheritance in equal shares by virtue of intestate succession ${ }^{33}$, which is undoubtedly shocking.

The reasons for deprivation of parental authority are set out in Article $111 \$ 1 \mathrm{FGC}^{34}$. Among them, the FGC provides, which is particularly relevant to the subject of this article, for abuse of parental authority by parents and gross neglect by parents of their duties towards the child. Both reasons seem to share the component of culpable violation of parental authority ${ }^{35}$. In the literature on the subject, abuse of parental authority is understood as the exercise by parents of the rights under parental

32 Hanna Witczak, "O skutkach wydziedziczenia w kontekście przesłanek nabycia spadku," in Państwo. Konstytucja. Prawo. Księga Pamiątkowa poświęcona Sędziemu Trybunatu Konstytucyjnego Profesorowi Henrykowi Ciochowi, Studia i Materiaty Trybunatu Konstytucyjnego, tom LX (Warszawa: Trybunał Konstytucyjny, 2018), 517-519.

33 As already mentioned earlier, testamentary succession is not possible in this case.

34 If any of the grounds set out in Article 111 FGC are found to exist, the court is obliged to deprive the parent(s) of parental authority. The article omits to discuss the case of optional deprivation of parental authority pursuant to Article $111 \$ 1$ a CC. Cf. Józef Strzebińczyk, "Pozbawienie władzy rodzicielskiej," in Prace z prawa cywilnego dla uczczenia pamięci Profesora Jana Kosika, Acta Universitatis Wratislaviensis. Prawo CCCVIII (Wrocław: Wydawnictwo Uniwersytetu Wrocławskiego, 2009), 477-479.

35 Krzysztof Pietrzykowski, "Komentarz do art. 111," in Kodeks rodzinny i opiekuńczy. Komentarz, ed. Krzysztof Pietrzykowski (Warszawa: C.H. Beck, 2020), Legalis, Nb 4. Cf. Jerzy Strzebińczyk, "Władza rodzicielska," in System Prawa Prywatnego. Tom 12. Prawo rodzinne i opiekuńcze, ed. Tadeusz Smyczyński (Warszawa: C.H. Beck, 2011), 353-353, Nb. 253-254. 
authority "in a manner seriously violating the best interest of the child" 36 . Examples of parental abuse include punishing children in ways that endanger their health or life, maltreatment, forcing a child to drink alcohol, forcing a child to immoral or antisocial acts, or even to commit prohibited acts. Very often, the abuse of parental authority manifests itself in the use of inappropriate parenting methods, which take various forms of aggression and physical and psychological violence ${ }^{37}$. Case-law shows that "Abuse of parental authority also occurs when the parent's conduct has, in objective terms, a damaging effect on the child's upbringing and mental development, even if this is not related to the parent's subjective negative attitude towards the child" 38 . Two groups of cases are identified linked to gross neglect of parental duties. One covers social pathology involving alcoholism, drug addiction, parents pursuing criminal activities, etc. which results in leaving the child unattended, ignoring their education needs or not securing decent living conditions. Letting a child live in a pathological environment poses an immediate threat to their health and life. The other group covers cases of lack of interest in the child and their affairs, lack of contact and, as a result, the dissolution of emotional ties ${ }^{39}$. It must be stressed that neglect of parental duties only justifies the withdrawal of parental authority if it is gross, i.e. serious, glaring, and discernible even to a random beholder ${ }^{40}$.

36 Karol Jagielski, “Istota i treść władzy rodzicielskiej," Studia Cywilistyczne 3 (1963): 155.

37 Elżbieta Holewińska-Łapińska, "Orzecznictwo w sprawach o pozbawienie władzy rodzicielskiej," in Prawo w dziataniu. Tom 14. Sprawy cywilne, ed. Elżbieta Holewińska-Łapińska (Warszawa: LEX a Wolters Kluwer Business, 2013), 53 and 57-58.

38 Decision of the Supreme Court of 7 September 2000, file ref. I CKN 931/00, LEX no. 1166290. Cf. Jacek Ignaczewski, "Przesłanki pozbawienia władzy rodzicielskiej," in Komentarz do spraw rodzinnych, ed. Jacek Ignaczewski (Warszawa: LexisNexis, 2012), 321.

39 For more, see Jacek Ignaczewski, "Przesłanki pozbawienia władzy rodzicielskiej," in Komentarz do spraw rodzinnych, ed. Jacek Ignaczewski (Warszawa: LexisNexis, 2012), 321-329 and Elżbieta Holewińska-Łapińska, "Orzecznictwo w sprawach o pozbawienie władzy rodzicielskiej," in Prawo w dziataniu. Tom 14. Sprawy cywilne, ed. Elżbieta Holewińska-Łapińska (Warszawa: LEX a Wolters Kluwer Business, 2013), 52-54 and 56-57.

40 Jerzy Strzebińczyk, "Pozbawienie władzy rodzicielskiej," in Prace z prawa cywilnego dla uczczenia pamięci Profesora Jana Kosika, Acta Universitatis Wratislaviensis. Prawo CCCVIII (Wrocław: Wydawnictwo Uniwersytetu Wrocławskiego, 2009), 483 and the literature referenced therein. 
That certain parents' behaviours that can be regarded as abuse of parental authority or gross neglect of their parental duties often meet the criteria of certain types of offences remains no longer debatable ${ }^{41}$. The literature on the subject emphasises that despite penal courts do not adjudge on the deprivation of parental authority, some views expressed in the doctrine and case-law regarding the type of offences that give sufficient grounds for the deprivation of parental authority are still legitimate. This is more than justified as there is invariably a close correlation between parents' crimes and abuse of parental authority or gross neglect of parental duties ${ }^{42}$. Research shows that in the vast majority of cases the reason for withdrawal of parental authority is gross neglect of duties towards the child by one or both parents ${ }^{43}$.

It seems that the last of the reasons for withdrawing parental authority is no longer so obvious in the context of the discussed subject. As in the same of culpable violation of parental authority, the court denies this authority to the parent or parents who are unable to exercise it due to a permanent obstacle. In the literature on the subject, the general term "permanent obstacle" is interpreted as an impediment that is reasonably expected to continue over a long and indefinite period or a definite one but spanning many years. For example, a parent leaves for another country and does not maintain contact with the child ${ }^{44}$, or is in a penitentiary

41 And sometimes also petty offences [e.g. exploitation of child begging (Article 104 of the Code of Petty Offences) or allowing a child under seven years of age to remain in circumstances hazardous to health (Article 106 of the Code of Petty Offences); for more, see Krzysztof Pietrzykowski, "Komentarz do art. 111," in Kodeks rodzinny i opiekuńczy. Komentarz, ed. Krzysztof Pietrzykowski (Warszawa: C.H. Beck, 2020), Legalis, Nb 9]. However, in such a case the institution of unworthiness to inherit will apply.

42 Iwona Długoszewska, Przestanki oraz skutki ograniczenia i pozbawienia wtadzy rodzicielskiej (Warszawa: LexisNexis, 2012), 279-280.

43 See Elżbieta Holewińska-Łapińska, "Orzecznictwo w sprawach o pozbawienie władzy rodzicielskiej," in Prawo w dziataniu. Tom 14. Sprawy cywilne, ed. Elżbieta Holewińska-Łapińska (Warszawa: LEX a Wolters Kluwer Business, 2013), 52-54 and 56. Cf. Henryk Dolecki, Ingerencja sądu w wykonywanie wtadzy rodzicielskiej (Warszawa: Wydawnictwo Prawnicze, 1983), 50.

44 Cf. Urszula Nowicka, "Pozbawienie władzy rodzicielskiej w polskim porządku prawnym," Ius Matrimoniale, no. 4 (2017): 16 and the literature referenced therein. 
facility, or has fallen ill ${ }^{45}$. No doubt failure to exercise parental authority for reasons not attributable directly to the mother or father should not produce such acute legal effects with regard to succession as a permanent obstacle to do so for reasons attributable to either parent.

\section{DEPRIVATION OF PARENTAL AUTHORITY AS GROUNDS FOR UNWORTHINESS TO INHERIT IN SELECTED FOREIGN LEGAL SYSTEMS}

Among the laws of succession effective in other countries, there are some which explicitly approach deprivation of parental authority as a reason for unworthiness to inherit, i.e. negative grounds for the acquisition of inheritance. The differences occur in the legal concept of unworthiness, which may bring ex lege consequences or produce effects by virtue of a decision of a constitutive court ${ }^{46}$, with entails further legal consequences. Among the solutions adopted in foreign legal systems, particular attention should be paid to Russian and Italian law due to the fact that they directly refer to the institution of deprivation of parental authority in the context of the admissibility of inheritance from a minor. It is also interesting to note that the legal systems of Germany, France, the Czech Republic or the Netherlands, the possibility of denying inheritance to minor testator's parents deprived of parental responsibility may, as in Polish law, only depend on the institution of unworthiness to inherit and may be related to the committing of a certain type of wilful offence against a minor testator,

45 See, for exmaple, Krzysztof Pietrzykowski, "Komentarz do art. 111," in Kodeks rodzinny i opiekuńczy. Komentarz, ed. Krzysztof Pietrzykowski (Warszawa: C.H. Beck, 2020), Legalis, Nb 5; Jerzy Strzebińczyk, "Pozbawienie władzy rodzicielskiej," in Prace z prawa cywilnego dla uczczenia pamięci Profesora Jana Kosika, Acta Universitatis Wratislaviensis. Prawo CCCVIII (Wrocław: Wydawnictwo Uniwersytetu Wrocławskiego, 2009), 481; idem, "Władza rodzicielska," in System Prawa Prywatnego. Tom 12. Prawo rodzinne i opiekuńcze, ed. Tadeusz Smyczyński (Warszawa: C.H. Beck, 2011), 353, Nb. 251 and Jacek Ignaczewski, "Przesłanki pozbawienia władzy rodzicielskiej," in Komentarz do spraw rodzinnych, ed. Jacek Ignaczewski (Warszawa: LexisNexis, 2012), 332.

46 This is an inaccurate wording as some legal systems adopt both models of unworthiness to inherit, e.g. Russian law, as discussed below, or French law. For more, see: Hanna Witczak, Wytaczenie od dziedziczenia na mocy orzeczenia sądu (Warszawa: LexisNexis, 2013), 74-79. 
with the proviso that sometimes a final conviction for such an offence in a criminal trial may be required ${ }^{47}$.

The Russian legislator has adopted the simplest solution, ex lege excluding from intestate succession the testator's parents who have been deprived of parental authority by a court decision that is valid upon the opening of the succession. Such parents are then referred to as absolutely unworthy heirs ${ }^{48}$. However, this legal concept of unworthiness adopted in Russian law, unlike that existing in Polish law, is not uniform ${ }^{49}$. On the one hand, an unworthy heir is a person who has no right to inherit due to circumstances listed in para. 1 of Article 1117 CC if confirmed by a court's decision; this is the case, for example ${ }^{50}$, with parents who were deprived of their parental rights by a court and did not hold these rights upon the opening of the succession (sentence 2, para. 1 of Article 1117 of the Russian Civil Code ["RCC”] $)^{51}$. On the other hand, an unworthy heir

47 Cf. $\$ 2339$ German CC; Article 726 French CC; $\$ 469$ Czech CC; Article 4:3 Dutch CC. Form more, see Hanna Witczak, Wytączenie od dziedziczenia na mocy orzeczenia sądu (Warszawa: LexisNexis, 2013), 292-298.

48 The analysis of the question of the effects of a court's decision withdrawing parental authority on the capacity to inherit from a testator should also cover situations in which there is inheritance from a testator who has reached the age of majority. First, in their will, such a testator may point to their parents as heirs, which may be regarded as an act of forgiveness; it may also be the case of intestate succession, subject to the condition that the testator is at the age of majority at the time of the opening of the succession at the latest.

49 Cf. Борис А. Булаевский, “Комментарий к статье 1117," in Комментарий к Гражданскому Кодексу Российской Федерации части третьей, eds. К. Б. Ярошенко and Н. И. Марышева (Москва 2011), thesis 3; Алексей Н. Гуев, Постатейный коментарий к части третьей Гражданского кодекса (Москва 2006), 30-31 and Лариса В. Саникова, “Комментарий k статье 1117," in Комментарий к части третьей Кодекса Российской Федерации, eds. Т. Е. Абова, М. М. Богуславский, and А. Г. Светланов, (Москва 2004), thesis 1.

50 Other circumstances excluding ex lege certain entities from inheritance as unworthy are listed in sentence 1, para. 1 of Article 1117 RCC, and the law excludes them both from intestate succession and succession by will. However, a closer analysis of these goes beyond the scope of this paper.

51 Restoration of parental rights is possible if grounds on which the mother or father was deprived of these rights have ceased to exist, in other words, they have changed their behaviour, lifestyle and view on child upbringing (Article 72(1) RCC). Courts investigate such cases at the request of persons who have been deprived of parental rights. Even if the parents have changed their behaviour and are able to bring the child up properly, the court will not examine the request if the child has already been adopted and when 
is a person who, in accordance with paragraph 2 of Article 1117 RCC, has been excluded from the succession by a court ${ }^{52}$. Grounds for absolute and relative unworthiness are varied. The legislator has also differentiated the consequences of unworthiness to inherit by limiting them in certain cases only to intestate succession.

In the literature on the subject, the first category of persons unworthy to inherit, i.e. those who fail to inherit through a court's decision confirming the existence of circumstances referred to in the aforesaid provision, including deprivation of parental authority, is sometimes referred to as "absolutely," "totally" or "definitely" unworthy. Persons excluded from the succession at the request of competent entities are referred to as "conventionally" or "relatively" unworthy. The idea of this division, as emphasised in the doctrine, is that no adjudication of unworthiness is required to recognise an heir from the former of the two groups as unworthy to inherit. As noted above, in this case, a court's decision, for example, depriving the testator's parents of parental authority, is sufficient ${ }^{53}$. This means that if a notary public has been submitted a court's decision depriving an heir of their parental rights in relation to the testator, and there is no evidence that these rights have been restored upon the opening of the succession, the notary may resolve the issue of unworthiness to inherit on their own and refuse to issue a certificate of succession to the potential heir. The heir has

the child, if over 10 years old, has objected to it, regardless of their motives. If the child is not yet 10 years old, the court should investigate the case, first, taking into account the child's opinion and, second, only in the child's best interest. See Hanna Witczak, Wytaczenie od dziedziczenia na mocy orzeczenia sadu (Warszawa: LexisNexis, 2013), 303.

52 For more, see Гайнан Э. Авилов, “Комментарий k статье 1117," in Комментарий к части третьей Кодекса Российской Федерации, eds. А. Л. Масковский and Э. А. Суханов (Москва 2002), thesis 1; Аалексей Н. Гуев, Постатейный комментарий к части третьей Гражданского кодекса (Москва 2006), 30-31 and Борис А. Булаевский, "Комментарий к статье 1117," in Комментарий к Гражданскому Кодексу Российской Федерации части третьей, eds. К. Б. Ярошенко and Н. И. Марышева, (Москва 2011), thesis 3.

53 Or a final sentence of a penal court declaring the heir guilty of an intentional offence. See Борис А. Булаевский, “Комментарий к статье 1117,” in Комментарий к Гражданскому Кодексу Российской Федерации части третьей, eds. К. Б. Ярошенко and Н. И. Марышева (Москва 2011), thesis 4; idem in Наследственное право, еd. К. Ярошенко (Москва 2005), 66. 
a right to challenge the notary's refusal before court ${ }^{54}$. Moreover, the distinction in question is important because the "absolutely" unworthy cannot participate in the succession relations, even if the other heirs and creditors agree to it and even wish for it to happen. The "relatively" unworthy, on the other hand, participate in the succession relations if the other heirs agree and "have not registered their active opposition" 55.

Deprivation of parental authority in Russian law is the ultimate measure of interference in the exercise of parental rights and is applied only when there are no other means of protecting the child's rights. This measure is employed where at least one of the grounds listed in Article 69 RCC exists; at the same time, judging by case-law, there is a strong emphasis that the deprivation of parental rights on the grounds provided for in the aforesaid article may only take effect in cases of culpable conduct of the father or mother ${ }^{56}$. These grounds partly coincide with those set out in Article 111 of the Polish CC. The shared elements include evading parental duties, including malicious avoidance to pay child support, leaving the child alone at home unattended and without a meal, which is considered non-concern for the child's spiritual and physical development, learning, and preparation for future work. Deprivation of parental authority may also follow parents' abuse of their rights in relation to the child, that is, exercising these rights in a manner that is contrary to the minor's interest, for example by hindering education, encouraging begging, thievery, prostitution, alcohol or drug abuse. The Russian legislator also provides for the sanction of deprivation of parental authority for a father or mother who treats his or her children in a cruel manner, in particular by using physical or mental violence or by assaulting their sexual integrity. Cruelty can also manifest itself in reprehensible child rearing methods, insults, exploitation, or crude treatment that disregards a child's dignity. The court will also deprive parents of their authority if they suffer from permanent

54 See, for example, Татьяна И. Зайцева and Павел В. Крашенинников, Наследственное право. Комментарий законодательства н практика его применениа (Москва 2009), 37-38 and Александр П. Горелик, Наследственное право (Москва-Воронеж 2011), 90-91.

55 Алексеев С. Василев, “Комментарий к к статье 1117," in Комментарий к Гражданскому Кодексу Российской Федерации. Части 1, 2, 3, 4 (учедно- практический), ed. С. А. Степанов (Москва), thesis 1 .

56 Алла В. Вишнякова, Семейное и наследственное право (Москва 2010), 112. 
alcoholism or drug addiction (confirmed by a medical opinion). The final reason for the withdrawal of parental authority is when the mother or father of a minor commits a crime against the life or health of their children or spouse.

In the current legal system of Italy, deprivation of parental authority is also considered grounds for unworthiness to inherit, although the relevant provisions were incorporated into the Italian Civil Code no earlier than in 2005 under Act No. 137. This change was a major improvement as it removed a crucial normative inconsistency: a parent deprived of parental authority lost the right to use the minor's property while retaining the right to acquire it mortis causa ${ }^{57}$. Parental authority is withdrawn by the decision of a family court only if the conditions set out in the law apply. Pursuant to Article 330 of the Italian Civil Code ("ICC"), a court may terminate parental authority when a parent violates or neglects their duties towards the child or abuses their powers to the serious detriment of the child ${ }^{58}$.

This will be discussed further, but in Italian law, unlike in Russian law, to exclude parents deprived of parental authority over their child from the succession, the legislator requires a constitutive court decision on unworthiness to inherit ${ }^{59}$. The prevailing view in the literature on the subject is that as with the other grounds for deprivation of parental rights so with the ground in the form of debarment from succession - there must be no automatism allowed whatsoever. The effect of denial of inheritance does not arise ipso iure; a court's judgement is required. Only if a legitimate entity has brought an appropriate action, which has been upheld by the court, the parent loses their rights in relation to their child's estate ${ }^{60}$.

57 Giovanni Bonilini and Massimo Conforlini, Codice commentato delle successioni e donazioni (Milano: Utet Giuridica, 2011), 177.

58 On the other hand, irrespective of the deprivation of parental authority, according to Article 463(1) ICC, persons may be considered unworthy to inherit if they intentionally killed or attempted to kill the testator or their spouse, descendant, or ascendant.

59 Gaetano Azzariti, Le successioni e le donazioni. Libro secondo del Coice civile (Napoli: CEDAM, 1990), 50. See also Giovanni Bonilini and Massimo Conforlini, Codice commentato delle successioni e donazioni (Milano: Utet Giuridica, 2011), 172-173 and 177.

60 Giovanni Bonilini and Massimo Conforlini, Codice commentato delle successioni e donazioni (Milano: Utet Giuridica, 2011), 177. 
In Italian law, withdrawing parental authority is also an additional penalty imposed in penal proceedings. According to Article 32(1) of the Italian Penal Code, if sentenced to life imprisonment, a parent is deprived of parental authority. The penalty of deprivation of parental authority, next to more general provisions, is also provided for in laws governing specific types of offences if parental authority is one of the statutory constituent elements of an offence, e.g. incest (Article 564 of the Italian Penal Code) or forcing a child to prostitution (Article 609 of the Italian Penal Code) ${ }^{61}$.

\section{DE LEGE FERENDA CONCLUSIONS AND RECOMMENDATIONS}

The observations shared above lead to a conclusion that the current legal solutions in Poland regarding the subject of the article should be assessed critically. What follows, proposals for legislative changes should be made. Some of these changes should address the provision of Article 928 $\$ 1 \mathrm{CC}$. First, it is necessary to consider whether it is sufficient to introduce an additional reason justifying the recognition of an heir as unworthy through deprivation of parental authority. The answer, unfortunately, seems to be negative. This is so for at least two reasons. First, the reasons for which a court may deprive parents of their authority are inconsistent. In other words, although most of them are related to culpable and reprehensible behaviour of the parents, some of them should not be attributed to them (e.g. severe, chronic parent's illness), yet they may prevent the exercise of parental authority on a permanent basis. Second, if the amended regulations were only to extend grounds for unworthiness to inherit by including the criterion of deprivation of the minor testator's parents of their parental authority, there would always be a risk of not excluding them from inheritance due to the lack of an appropriate request by the entitled entity or bringing an action after the time limit specified in sentence 2 or Article 929 CC. It does not seem right if such significant legal consequences as regards the acquisition of an inheritance from a minor testator are left to chance. Hence, it is no less important to be considered whether

${ }^{61}$ See Hanna Witczak, Wytaczenie od dziedziczenia na mocy orzeczenia sądu (Warszawa: LexisNexis, 2013), 305 and the literature referenced therein. 
the concept of unworthiness to inherit in Polish law is sufficient enough to effectively sanction cases of depriving the parents of a minor testator of parental authority.

By proposing de lege ferenda conclusions, because there is no question that the discussed problem should be addressed, it must not be ignored that the normative shape of the institution of unworthiness to inherit may be based on one of two models: either unworthiness occurs ipso iure and is qualified as a relative incapacity to inherit (incapacitas) or is the result of a constitutive court decision at the request of entitled entities and constitutes unworthiness in the strict sense (indignitas) ${ }^{62}$. In the first case, when determining the group of heirs, the court ex officio examines grounds for unworthiness; in the second case, it only decides on unworthiness when a relevant request is submitted by an entity enjoying active rights in proceedings related to establishing inheritance unworthiness.

With regard to the institution of unworthiness to inherit in Polish law, both of the concepts discussed above were in use although at different times $^{63}$. There is no doubt that the legal concept of unworthiness to inherit in the current legal framework is rested on the latter of the two models. Inheritance unworthiness is decided on the basis of a constitutive court decision (the provision of Article $928 \$ 1$ CC provides expressis verbis that "an heir may be adjudged unworthy by the court"). The court's decision

62 Maksymilian Pazdan, "Niegodność dziedziczenia w polskim prawie prywatnym międzynarodowym," Nowe Prawo, no. 2 (1974): 149. As mentioned earlier, some foreign jurisdictions adopt both models (see Note 38). For more, see: Hanna Witczak, Wytączenie od dziedziczenia na mocy orzeczenia sądu (Warszawa: LexisNexis, 2013), 71-81.

63 As for the legal nature of unworthiness to inherit the provisions of the Decree of 8 October 1946 Law of Succession (Journal of Laws No. 60, item 328), divergent opinions were voiced in the literature. There was no agreement as to whether the provisions of Articles 7-9 of the Decree concern unworthiness in the strict sense or a relative unworthiness to inherit. Cf. Article 63(3) of the Decree of 8 November 1946 on Succession Proceedings (Journal of Laws No. 63, item 346). Zob. Adam Kozaczka, "Z zagadnień niegodności dziedziczenia w polskim prawie spadkowym," in Rozprawy prawnicze. Ksiegga pamiątkowa dla uczczenia pracy naukowej Kazimierza Przybytowskiego, eds. Wacław Osuchowski, Mieczysław Sośniak, and Bronisław Walaszek (Kraków-Warszawa: Państwowe Wydawnictwo Naukowe, 1964), 143 and Hanna Witczak, Wytaczenie od dziedziczenia na mocy orzeczenia sadu (Warszawa: LexisNexis, 2013), 67-71 and the literature referenced therein. 
produces as effect ex tunc; an unworthy heir is excluded from the succession as if they were no longer alive during the opening of the succession (Article $928 \$ 2 \mathrm{CC})^{64}$, and the exclusion from inheritance occurs only when the decision becomes final ${ }^{65}$. This construct of the institution produces certain practical consequences, in particular such that "notification of unworthiness to inherit" now requires bringing an action. It is not possible for the court to establish unworthiness in proceedings regarding confirmation of acquisition of an inheritance; in the event that an argument of unworthiness is raised in such proceedings, the case is suspended until the issue of unworthiness to inherit is resolved in another procedure ${ }^{66}$.

It should be noted that also in Italian regulations on inheritance unworthiness, it is considered a certain type of sanction under civil law that works as a prerequisite for exclusion from inheritance under a constitutive court's decision. Because unworthiness to inherit is qualified as ex post exclusion from the succession, it is necessary for entitled entities to bring an appropriate action. Such a position is uniform across case-law. Although opinions in the doctrine are divided, the prevailing view also shows that unworthiness to inherit, unlike incapacity to inherit, does not in itself deny title to inherit, yet it deprives the right to acquire an inheritance on the basis of a constitutive court's decision issued upon a party's request and respecting the principle indignus potest capere sed non potest retinere (the unworthy has the right to acquire but may not keep $)^{67}$. Hence, it should be regarded as a reason for denying an inheritance, for the application of officio iudicis, and a causative factor preventing the party unworthy to inherit from

64 See, for example, justification for the Decision of the Supreme Court of 3 February 2012, file ref. I CZ 9/12, Legalis.

65 See, for example, justification for the Decision of the Supreme Court of 30 January 2015, file ref. III CSK 140/14, LEX no. 1651011 and justification for the Judgement of the Administrative Court in Kraków of 20 May 2014, file ref. I ACa 357/14, LEX no. 1587205. For more, see: Hanna Witczak, "Komentarz do art. 928," in Kodeks cywilny. Komentarz. Tom IV. Spadki (art. 922-1087), eds. Magdalena Habdas and Mariusz Fras (Warszawa: Wolters Kluwer, 2019), thesis 2.

66 Zob. Janusz Pietrzykowski, in Kodeks cywilny. Komentarz. Tom 3. Ksiega czwarta - Spadki. Przepisy wprowadzające Kodeks cywilny, ed. Janusz Pietrzykowski (Warszawa: Wydawnictwo Prawnicze, 1972), 1837.

67 Giovanni Bonilini, Manuale di diritto ereditario e delle donazioni (Torino: Utet Giuridica, 2010), 43ff. 
keeping their acquired rights ${ }^{68}$. Therefore, the supporters of the presented position approach this institution as having attributes typical of exclusion from an inheritance ex post and assume that the unworthy party acquires an inheritance and then loses it ex tunc once a court adjudges their unworthiness ${ }^{69}$. Only some representatives of the doctrine perceive this institution as a "form" of relative incapacity to inherit (in relation to de cuius) and as an imposed private penalty ${ }^{70}$. They emphasize that although in practice unworthiness to inherit may overlap with incapacity, there are some conceptual differences between them which, due to their importance, cannot be ignored. For example, a person considered unworthy has the "capacity to rehabilitate," which is not the case with incapacity to inherit. There are also differences in the scope of application: it is limited in the case of unworthiness to inherit which applies to a strictly defined person and prevents inheritance from a specific testator, while incapacity to inherit is more general, unlimited, and not linked to the deceased. Based on this concept, unworthiness to inherit would be an obstacle to the acquisition of an inheritance as a sanction for perpetration of a particularly reprehensible act. That sanction would occur ipso iure, thus making it impossible to acquire an inheritance ${ }^{71}$. The practical consequences of adopting one of the concepts of unworthiness to inherit are anything but trifling. In the case of incapacity, the legal consequences are automatic without court, and therefore no intervention of a judge is required; according to the other concept, such intervention is necessary because there is acquisition of an inheritance that comes into play, and its retroactive reversal is possible only through a constitutive court's decision. Russian law adopts a different solution. Parents deprived of parental authority are ex lege excluded from the succession as absolutely unworthy heirs.

68 Gaetano Azzariti, Le successioni e le donazioni. Libro secondo del Coice civile (Napoli: CEDAM, 1990), 37ff.

69 Giovanni Bonilini, Manuale di diritto ereditario e delle donazioni (Torino: Utet Giuridica, 2010), 474.

70 See Cesare M. Bianca, Diritto civile. II. La famiglia - Le succesioni (Milano: Giuffrè, 2001), 482.

71 Luigi Ferri, "Succesioni in generale. Art. 456-511," in Commentario del codice civile, eds. A. Scaloja and G. Branca (Bologna-Roma: Utet Guardica, 1997), 175. 
Given the considerations above, reasonable doubts arise as to whether the legislative solution adopted in Polish law of succession should also be applied in cases of depriving the parents of a minor testator of parental authority if it gives grounds to unworthiness to inherit ${ }^{72}$. Unworthiness in the strict sense means, as mentioned elsewhere, the acquisition of an inheritance by an heir, which is then lost on the basis of a constitutive court's decision. Grounds for unworthiness may therefore arise both before and after the opening of the succession, and the testator's act of forgiveness ${ }^{73}$ removes its effects. This would highlight another difference, namely the adoption of unworthiness in the strict sense by ordinary legislation when they aim to exclude a specific person's title to inherit in the testator's best interest ${ }^{74}$. Meanwhile, a person with a relative incapacity to inherit does not acquire an inheritance at all, and this incapacity effect occurs ipso iure ${ }^{75}$. The relative incapacity to inherit works "automatically erga omnes" upon the opening of the succession, i.e. without the need to determine or adjudge it in a special court's judgement ${ }^{76}$. There is no controversy that this "shape" of this institution requires that grounds for unworthiness arise before the opening of the succession. Characteristic of this concept of unworthiness is that, in principle, it is impossible to remove the consequences of unworthiness by testator's pardon. As underlined in the literature on the subject, this is because "ordinary legislations resort to

72 Of course, if we agree with the idea that it should exclude the parents of the deceased from the group of heirs.

73 Who does not have to have full legal capacity, it is enough for them to act with "sufficient understanding" (see Article $1010 \$ 2$ CC).

74 Jan Gwiazdomorski, Prawo spadkowe (Warszawa: Państwowe Wydawnictwo Naukowe, 1959), 72. Cf. Alfred Ohanowicz, "Recenzja pracy J. Gwiazdomorski 'Prawo spadkowe' (PWN: Warszawa, 1959) 468,” Ruch Prawniczy, Ekonomiczny i Socjologiczny, no. 41 (1959): 193-194.

75 Jan Gwiazdomorski, Przepisy ogólne dotyczące spadków, dziedziczenie ustawowe, testament (Katowice: Wydawnictwo Zrzeszenia Prawników Polskich, 1965), 20.

76 Adam Kozaczka, "Z zagadnień niegodności dziedziczenia w polskim prawie spadkowym," in Rozprawy prawnicze. Księga pamiątkowa dla uczczenia pracy naukowej Kazimierza Przybytowskiego, eds. Wacław Osuchowski, Mieczysław Sośniak, and Bronisław Walaszek (Kraków-Warszawa: Państwowe Wydawnictwo Naukowe, 1964), 143. 
the concept of relative incapacity to inherit when they intend to exclude the title for inheritance of a certain person for general and social reasons"77.

It seems that the deprivation of parental authority should not only be included among grounds justifying unworthiness to inherit, but, in this case, it is reasonable to apply a different model of this institution than the one selected by the legislator in Articles 928-930 CC. Such heirs should be excluded from inheritance ex lege, that is, without the requirement of a civil court's decision in connection with an action brought within the time limit specified in the law for declaring the heir unworthy to inherit. Of course, whether the relevant regulation should be incorporated into the provisions on unworthiness to inherit or, due to the relevant exclusion, in the provisions on intestate succession is still debatable. If added to the Civil Code, Article $932^{1}$ could, for example, provide that the provisions on the intestate title to inherit do not apply to the testator's parents who, upon the opening of the succession, are deprived of parental authority. Undoubtedly, due to the different nature of grounds for withdrawing parental authority, amendments would also be advisable to the provisions of the Family and Guardianship Code. It would be necessary to clearly separate the culpable and non-culpable causes of such withdrawal. By doing so, it would be possible to point to the legal basis for deprivation of parental authority, which would only highlight the culpable causes for such a court's decision. Given the proposed changes, it also seems appropriate to make relevant notes in civil registers.

\section{REFERENCES}

Авилов, Гайнан Э. “Комментарий k статье 1117.” In Комментарий к части третьей Кодекса Российской Федерации, edited by A. Л. Масковский, and Э. А. Суханов, thesis 1. Москва 2002.

Azzariti, Gaetano. Le successioni e le donazioni. Libro secondo del Coice civile. Napoli: CEDAM, 1990.

Bianca, Cesare. Diritto civile. II. La famiglia-Le succesioni. Milano: Giuffrè, 2001.

77 Jan Gwiazdomorski, Prawo spadkowe (Warszawa: Państwowe Wydawnictwo Naukowe, 1959), 73. 
Bonilini, Giovanni. Manuale di diritto ereditario e delle donazioni. Torino: Utet Giuridica, 2010.

Bonilini, Giovanni, and Massimo Conforlini. Codice commentato delle successioni e donazioni. Milano: Utet Giuridica, 2011.

Булаевский, Борис А. “Комментарий к статье 1117.” In Комментарий к Гражданскому Кодексу Российской Федерации части третьей, edited by К. Б. Ярошенко, and Н. И. Марышева, thesis 4. Москва 2011.

Булаевский, Борис А. “Комментарий к статье 1117.” In Комментарий к Гражданскому Кодексу Российской Федерации части третьей, edited by К. Б. Ярошенко, and Н. И. Марышева, thesis 3. Москва 2011.

Długoszewska, Iwona. Przestanki oraz skutki ograniczenia i pozbawienia wtadzy rodzicielskiej. Warszawa: LexisNexis, 2012.

Dolecki, Henryk. Ingerencja sądu w wykonywanie wtadzy rodzicielskiej. Warszawa: Wydawnictwo Prawnicze, 1983.

Ferri, Luigi. "Succesioni in generale. Art. 456-511." In Commentario del codice civile, edited by A. Scaloja, and G. Branca. Bologna-Roma: Utet Guardica, 1997.

Goettel, Mieczysław. "Pozbawienie praw rodzicielskich w polskim kodeksie karnym." Nowe Prawo, no. 7-8 (1978): 1077-1089.

Горелик, Александр П. Наследственное право. Москва-Воронеж 2011.

Гуев, Алексей Н. Постатейный коментарий к части третьей Гражданского кодекса. Москва 2006.

Gudowski, Jacek, ed. Kodeks cywilny. Komentarz. Spadki. IV. Warszawa: Wolters Kluwer Polska, 2017.

Gwiazdomorski, Jan. Prawo spadkowe. Warszawa: Państwowe Wydawnictwo Naukowe, 1959.

Gwiazdomorski, Jan. Przepisy ogólne dotyczące spadków, dziedziczenie ustawowe, testament. Katowice: Wydawnictwo Zrzeszenia Prawników Polskich, 1965.

Holewińska-Łapińska, Elżbieta. "Orzecznictwo w sprawach o pozbawienie władzy rodzicielskiej." Prawo w dziataniu. Tom 14. Sprawy cywilne (2013): 27-76.

Hypś, Sławomir. "Komentarz do art. 200.” In Kodeks karny. Komentarz, edited by Alicja Grześkowiak, and Krzysztof Wiak. Warszawa: C.H. Beck, 2021, Legalis.

Ignaczewski, Jacek. "Przesłanki pozbawienia władzy rodzicielskiej." In Komentarz do spraw rodzinnych, edited by Jacek Ignaczewski, 319-340. Warszawa: LexisNexis, 2012.

Jagielski, Karol. "Istota i treść władzy rodzicielskiej." Studia Cywilistyczne 3 (1963): 97-161.

Kłak, Paweł. "Glossary." OSP, no. 9 (2005): 81-90. 
Konarska-Wrzosek, Violetta. "Poddanie sprawcy próbie." In System Prawa Karnego. Tom 6. Kary i środki karne, edited by Mirosława Melezini. Warszawa: C.H. Beck, 2010, Legalis.

Kozaczka, Adam. "Z zagadnień niegodności dziedziczenia w polskim prawie spadkowym.” In Rozprawy prawnicze. Ksiega pamiątkowa dla uczczenia pracy naukowej Kazimierza Przybytowskiego, edited by Wacław Osuchowski, Mieczysław Sośniak, and Bronisław Walaszek, 143-150. Kraków-Warszawa: Państwowe Wydawnictwo Naukowe, 1964.

Kremis, Józef. “Komentarz do art. 1008." In Kodeks cywilny. Komentarz, edited by Edward Gniewek, and Piotr Machnikowski. Warszawa: C.H. Beck, 2016, Legalis.

Kuźmicka-Sulikowska, Joanna. "Komentarz do art. 1008." In Kodeks cywilny. Komentarz, edited by Edward Gniewek, and Piotr Machnikowski. Warszawa: C.H. Beck, 2019, Legalis.

Mierzwińska-Lorencka, Joanna. Karnoprawna ochrona dziecka przed wykorzystaniem seksualnym. Warszawa: Wolters Kluwer Polska, 2012.

Niedośpiał, Michał. “Glossary.” OSA, no. 6 (2006): 76-88.

Nowicka, Urszula. "Pozbawienie władzy rodzicielskiej w polskim porządku prawnym." Ius Matrimoniale, no. 4 (2017): 15-28.

Ohanowicz, Alfred. "Recenzja pracy J. Gwiazdomorski 'Prawo spadkowe' (PWN: Warszawa, 1959) 468.” Ruch Prawniczy, Ekonomiczny i Socjologiczny, no. 41 (1959): 193-194.

Pazdan, Maksymilian. "Komentarz do art. 1008." In Kodeks cywilny. Tom II. Komentarz. Art. 450-1088. Przepisy wprowadzajace, edited by Krzysztof Pietrzykowski. Warszawa: C.H. Beck, 2021, Legalis.

Pazdan, Maksymilian. "Komentarz do art. 928." In Kodeks cywilny. Tom II. Komentarz. Art. 450-1088. Przepisy wprowadzajace, edited by Krzysztof Pietrzykowski. Warszawa: C.H. Beck, 2021, Legalis.

Pazdan, Maksymilian. "Niegodność dziedziczenia w polskim prawie prywatnym międzynarodowym." Nowe Prawo, no. 2 (1974): 143-153.

Piątowski, Józef Stanisław, Hanna Witczak, and Agnieszka Kawałko. "Dziedziczenie ustawowe." In System Prawa Prywatnego. Tom 10. Prawo spadkowe, edited by Bogudar Kordasiewicz. Warszawa: C.H. Beck, 2015, Legalis.

Pietrzykowski, Janusz, ed. Kodeks cywilny. Komentarz. Tom 3. Księga czwarta-Spadki. Przepisy wprowadzajace Kodeks cywilny. Warszawa: Wydawnictwo Prawnicze, 1972.

Pietrzykowski, Krzysztof. "Komentarz do art. 111." In Kodeks rodzinny i opiekuńczy. Komentarz, edited by Krzysztof Pietrzykowski. Warszawa: C.H. Beck, 2020, Legalis. 
Przybyłowski, Kazimierz. "Notka do uchwały SN z dnia 10 września 1958 r. (3 CO 16/58).” OSPiKA, no. 5 (1959): 244-245.

Саникова, Лариса В. “Комментарий k статье 1117.” In Комментарий к части третьей Кодекса Российской Федерации части третьей, edited by T. Е. Абова, М. М. Богуславский, and А. Г. Светланов, thesis 1. Москва 2004.

Skowrońska, Elżbieta. "Przegląd orzecznictwa z zakresu prawa spadkowego (za lata 1989-1990).” Przegląd Sądowy, no. 9 (1992): 47-66.

Skowrońska-Bocian, Elżbieta. Testament w prawie polskim. Warszawa: LexisNexis, 2004.

Strzebińczyk, Jerzy. "Pozbawienie władzy rodzicielskiej." In Prace z prawa cywilnego dla uczczenia pamięci Profesora Jana Kosika, Acta Universitatis Wratislaviensis. Prawo CCCVIII, 475-495. Wrocław: Wydawnictwo Uniwersytetu Wrocławskiego, 2009.

Strzebińczyk, Jerzy. "Władza rodzicielska." In System Prawa Prywatnego. Tom 12. Prawo rodzinne i opiekuńcze, edited by Tadeusz Smyczyński, 233-389. Warszawa: C.H. Beck, 2011.

Василев, Алексей С. “Комментарий к к статье 1117.” In Комментарий к Гражданскому Кодексу Российской Федерации. Части 1, 2, 3, 4 (учедно- практический), edited by С. А.Степанов, thesis 1 . Москва.

Wierciński, Jacek. "O przestępstwie jako przyczynie niegodności dziedziczenia." Kwartalnik Prawa Prywatnego, no. 2 (2010): 555-569.

Wierciński, Jacek. "Uwagi o teoretycznych założeniach dziedziczenia ustawowego." Studia Prawa Prywatnego, no. 2 (2009): 79-92.

Witczak, Hanna. "Komentarz do art. 928." In Kodeks cywilny. Komentarz. Tom IV. Spadki (art. 922-1087), edited by Magdalena Habdas, and Mariusz Fras, 128-173. Warszawa: Wolters Kluwer Polska, 2019.

Witczak, Hanna. "O skutkach wydziedziczenia w kontekście przesłanek nabycia spadku." In Państwo. Konstytucja. Prawo. Księga Pamiątkowa poświęcona Sędziemu Trybunatu Konstytucyjnego Profesorowi Henrykowi Ciochowi, Studia i Materiaty Trybunatu Konstytucyjnego, tom LX, 513-521. Warszawa: Trybunał Konstytucyjny, 2018.

Witczak, Hanna. "Skutki wyłączenia od dziedziczenia." Rejent, no. 3 (2009): 73-96.

Witczak, Hanna. Wytaczenie od dziedziczenia na mocy orzeczenia sądu. Warszawa: LexisNexis, 2013.

Вишнякова, Алла В. Семейное и наследственное право. Москва 2010.

Зайцева, Татьяна И., and Павел В. Крашенинников. Наследственное право. Комментарий законодательства н практика его применениа. Москва 2009. 